\title{
Evaluation of the Efficacies of Selected Medicinal Plants on Pathogenic Escherichia Coli Strains
}

\author{
Momotaz Khanom*, Sharmin Sultana Khushi, Md. Golam Sarower \\ Fisheries and Marine Resource Technology Discipline \\ Khulna University, Khulna, Bangladesh \\ momotaz_khanom@yahoo.com,khushi.09ku@gmail.com,sarower@yahoo.com
}

\begin{abstract}
The medicinal plants are used in traditional treatments to cure variety of diseases for thousands of year. The aim of this study was to identify such plants with antimicrobial efficacy for controlling some pathogenic Escherichia coli strains. The locally available plants viz., garlic (Allium sativum), turmeric (Curcuma longa), crown flower (Calotropis gigentica), and Indian lilac (Azadirachta indica) were selected for the study. Ethanol extracts of these plants at two different doses (500- and $1000 \mu \mathrm{g} /$ disc) were examined against pathogenic E. coli strains using disc diffusion method as compared with standard kanamycin (30 $\mu$ g/disc.) Antibacterial activity was determined by measuring growth inhibition zones of E. coli strains. E. coli 119-EAE was more sensitive to all experimented extracts of medicinal plants except crown flower at the rate of 1000 $\mu \mathrm{g} /$ disc than other three strains. At the both concentration, the ethanol mixed extracts of crown flower and Indian lilac was most effective towards all E. coli strains. These extracts demonstrated the highest antibacterial activity against E. coli 119-EAE inhibiting its growth (21mm zone of diameter) at the dose of 1000 $\mu$ g/disc compared to standard antibiotic, kanamycin followed by Indian lilac and turmeric. The extracts of garlic exhibited the lowest inhibitory responses to all test organisms apart from E. coli 119-EAE strains. Furthermore, for in vivo challenge test of shrimps (Penaeus monodon), by using ethanolic mixed extracts of crown flower and Indian lilac the lowest average bacterial load of E. coli was observed to be $2.11 \times 10^{4} \mathrm{CFU} / \mathrm{g}$ at the concentration of $1000 \mu \mathrm{g} / \mu \mathrm{l}$ in muscle of shrimp reducing from $3.09 \times 10^{4} \mathrm{CFU} / \mathrm{g}$ found without applying extracts as control. These results suggested that there was strong antagonistic activity of ethanolic mixed extract of crown flower and Indian lilac against the strain of E. coli and it can be used in favor of proper fish health management controlling the risk of contamination from pathogenic E. coli in shrimp as important source of drugs.
\end{abstract}

Keywords: Medicinal plants, Standard kanamycin, Escherichia coli Strains, Antibacterial activity, Shrimp.

\section{INTRODUCTION}

Most of Escherichia coli strains are harmless, but only a small percentage is pathogenic to humans. The widespread occurrence of waterborne infections of E. coli origin in humans has become one of the major health problems worldwide. Hitherto, several types of enterovirulent $E$. coli have been recognized as the aetiologic agents of various gastrointestinal infections in humans. There are four classes of enterovirulent $E$. coli collectively known as the EEC group. This group is comprised of enterohemorrhagic E. coli (EHEC), which produces Shiga-like toxin and attaching-effacing lesions; enterotoxigenic $E$. coli (ETEC), producing heat-stable or heat-labile enterotoxins; enteroinvasive $E$. coli (EIEC), that causes bacillary dysentery via invasion of intestinal epithelial cells or by cytotoxin and enterotoxin; and enteropathogenic E. coli (EPEC), whose mechanism of virulence is thought to be unrelated to the excretion of typical $E$. coli enterotoxins. Traditionally cultured shrimp farms in Bangladesh are highly susceptible to be contaminated with such pathogenic E. coli strains because of lack of proper sanitation near these farms whereas shrimp is the second most important source of export accounting for a yearly earning of over \$US 300 million. Shrimp production in Bangladesh has suffered production decline due to viral and bacterial diseases.

Control of fish disease is currently based almost entirely on chemotherapy applied in aquaculture for over 50 years [1] and it will entirely retain a role in the management of fish culture systems [2]. The customary use of antibiotic might lead to bacterial resistance against it and intensification of unacceptable residues in aquaculture products and environment. The resistant bacterial strains might have a great negative consequence on the therapy of fish diseases or human diseases and environment 
of fish farms [3]. As, antibiotics are always associated with side effects [4], using antimicrobial compounds from medicinal plants has more advantage because of its degradation nature [5]. This scenario actually brings human to new medical dilemma [6]. The natural products are found to be more effective with least side effects as compared to commercial antibiotics so that reason they are used an alternated remedy for treatment of various infections [7]. Medicinal plants having therapeutic properties exert beneficial pharmacological effects on the animal body ecofriendly and produce antioxidant and antimicrobial properties which save the host from cellular oxidation reactions and other pathogens $[8,9]$. A scientific study to investigate the antibacterial activity of the medicinal plants, guava (Psidium guajava) against bacteria pathogenic for shrimp was initiated by Direkbusarakom and Aekpanithanpong (1992) [10] and turmeric (Curcuma longa) powder used in reducing the severity of white spot syndrome in shrimp reported by Rao (1996) [11]. Kraus et al. [12] reported that extract of different parts of Indian lilac (Azadirachta indica) possess fungicidal and bactericidal properties. Das et al. [13] tested the antibacterial activity of Indian lilac against Aeromonas hydrophila, Pseudomonas fluorescens, E. coli and Myxobacteria. Externally garlic (Allium sativum) is used as disinfectant and it is applied to indolent tumours, ulcerated surface and wounds [14]. It was reported that extract obtained from garlic was also highly effective against two tested bacteria, A. hydrophila and P. fluorescens (MIC $0.6 \mathrm{mg} / \mathrm{ml}$ ) [15]. The powdered root bark of Calotropis gigantea, commonly known as Crown flower is used to ease diarrhoea and dysentery, syphilis, coughs, asthma and fevers. Garlic, turmeric, crown flower and Indian lilac could be used as an alternative therapeutic measure against bacterial infection of fish [16]. But sporadic findings from the previous studies could not satisfy a suitable prevention and control measures. Considering the above aspects, the present study was conducted to investigate the therapeutic effect of medicinal plants on pathogenic E. coli strains and suggest a package in favor of proper health management in the aquaculture of Bangladesh by comparing the efficacies of selected antibiotic (kanamycin) and medicinal plants on common bacterial fish pathogens.

\section{Materials AND Methods}

\subsection{Selection of Medicinal Plants}

Four medicinal plants viz., garlic (Allium sativum), turmeric (Curcuma longa), crown flower (Calotropis gigentica), and leaves of Indian lilac (Azadirachta indica) and mixed of crown flower (Calotropis gigentica) and Indian lilac (Azadirachta indica) were applied for this study collected from the adjacent area of Khulna University, Khulna.

\subsection{Extracts Preparation of Plants}

Shade dried garlic, turmeric, crown flower, and leaves of Indian lilac and mixed of crown flower and Indian lilac was grinded into a coarse powder with the help of grinder and powder was stored in an airtight container and kept in a cool, dark and dry place. About $19.92 \mathrm{gm}, 190 \mathrm{gm}, 60 \mathrm{gm}$ and 115.5 gm of powdered material of turmeric, Indian lilac, garlic and crown flower were soaked in $75 \mathrm{ml}, 550$ $\mathrm{ml}, 150 \mathrm{ml}, 500 \mathrm{ml}$ of $100 \%$ ethanol, respectively in glass container kept for a period of 15 days accompanying regular shaking and stirring. It was filtered using a piece of clean, white cotton plug and dried using rotary vacuum evaporator (Bibby RE200, Sterilin Ltd., U.K.) at $45^{\circ} \mathrm{C}$ to get the dried methanol extract. Then the crude extract was stored in a refrigerator at $4^{\circ} \mathrm{C}$ until the experiment commenced. The extracted powder was dissolved in sterilized distilled water to make $500 \mu \mathrm{g} / \mathrm{ml}$ and $1000 \mu \mathrm{g} / \mathrm{ml}$ solution. These mixtures were used to perform antibacterial assay.

\subsection{Pathogenic Bacterial Strains}

The following four pathogenic isolates of bacterial strains isolated from shrimp farms were used for the study: E. coli 119-EAE, E. coli 312-ST, E. coli 424-PHO, and E. coli 521-LT2. All these cultures were maintained on nutrient agar plates at $37^{\circ} \mathrm{C}$ according to the method described by Chowdhury and Muniruzzaman [17].

\subsection{Antibacterial Activity Test}

Antibacterial activity of ethanol extract of garlic, turmeric, crown flower, and leaves of Indian lilac and mixed of crown flower and Indian lilac was determined by disc diffusion method [18] being widely acceptable for the preliminary screening of antibacterial activity. Reference microorganisms from the stock were streaked onto nutrient agar plates and the inoculated plates were incubated overnight at $37^{\circ} \mathrm{C}$. Small portion of the subculture was transferred into nutrient broth and incubated $(2-4 \mathrm{~h})$ at $37^{\circ} \mathrm{C}$ until the growth reached $\log$ phase. Nutrient agar media seeded with standard 
inoculums suspension was poured in Petri-dishes and allowed to solidify. Discs impregnated with extract (500/disc, $1000 \mu \mathrm{g} / \mathrm{disc}$ ), standard antibiotic disc (Kanamycin at $30 \mu \mathrm{g} / \mathrm{disc}$ ) and blank (solvent ethanol) discs were placed on the Petri dishes and gently pressed to ensure contact with the inoculated agar surface and then finally incubated at $37^{\circ} \mathrm{C}$ for $18-24 \mathrm{~h}$. Triplicate plates were maintained for each organism.

\subsection{Determination of Zone of Inhibition}

After proper incubation, the antibacterial activity of the test agents was determined by measuring the diameter of zone of inhibition in term of millimeter with calibrated digital slide calipers $[18,19]$ and assessed against a panel of four pathogenic bacterial strains at the dose of $500 \mu \mathrm{g} / \mathrm{disc}$ and 1000 $\mu \mathrm{g} / \mathrm{disc}$ and the results were compared with the activity of standard kanamycin $(30 \mu \mathrm{g} / \mathrm{disc})$.

\subsection{In Vivo Challenge Test of Ethanolic Extract}

In-vivo challenge test of ethanolic extract of garlic, turmeric, crown flower and leaves of Indian lilac and mixed of crown flower and Indian lilac on the experimental shrimps was done with the following steps.

\subsubsection{Experimental Setup}

In total, 44 shrimps with an average weight of $50 \pm 3 \mathrm{~g}$ were randomly distributed into 11 aquaria each $(4 \times 4 \times 4 \mathrm{~cm})$ containing 4 shrimp individual. The experiment was set up with a completely randomized design in treatments. Eleven treatments were used with five at $500 \mu \mathrm{g} / \mu \mathrm{l}$ and five for $1000 \mu \mathrm{g} / \mu \mathrm{l}$ : Control $\left(\mathrm{T}_{\mathrm{C}}\right)$, extract was not included and shrimps were injected with pathogenic $E$. coli, $\left(\mathrm{T}_{1}\right) 500 \mu \mathrm{g} / \mu \mathrm{l}$ garlic extract was included and shrimps were injected with pathogenic E. coli, $\left(\mathrm{T}_{2}\right) 500$ $\mu \mathrm{g} / \mu \mathrm{l}$ turmeric extract was included and shrimps were injected with pathogenic E. coli, $\left(\mathrm{T}_{3}\right) 500 \mu \mathrm{g} / \mu \mathrm{l}$ crown flower extract was included and shrimps were injected with pathogenic E. coli, $\left(\mathrm{T}_{4}\right) 500 \mu \mathrm{g} / \mu \mathrm{l}$ leaves of Indian lilac extract was included and shrimps were injected with pathogenic E. coli, $\left(\mathrm{T}_{5}\right) 500$ $\mu \mathrm{g} / \mu \mathrm{l}$ mixed of crown flower and Indian lilac extract was included and shrimps were injected with pathogenic E. coli. ( $\left.\mathrm{T}_{6}\right) 1000 \mu \mathrm{g} / \mu \mathrm{l}$ garlic extract was included and shrimps were injected with pathogenic E. coli, $\left(\mathrm{T}_{7}\right) 1000 \mu \mathrm{g} / \mu \mathrm{l}$ turmeric extract was included and shrimps were injected with pathogenic E. coli, $\left(\mathrm{T}_{8}\right) 1000 \mu \mathrm{g} / \mu \mathrm{l}$ crown flower extract was included and shrimps were injected with pathogenic E. coli, $\left(\mathrm{T}_{9}\right) 1000 \mu \mathrm{g} / \mu \mathrm{l}$ leaves of Indian lilac extract was included and shrimps were injected with pathogenic $E$. coli and $\left(\mathrm{T}_{10}\right) 1000 \mu \mathrm{g} / \mu \mathrm{l}$ mixed of crown flower and Indian lilac extract was included and shrimps were injected with pathogenic E. coli.

\subsubsection{Preparation of Injecting Solution and Method of Injection}

Bacterial colony of one strain of E. coli was collected with isolating loop and mixed (1 loop full in 1 ml) properly with Alkaline Saline Peptone Water (ASPW) in sterilized test tubes and further used for administration. One $\mathrm{ml}$ of 500 and $1000 \mu \mathrm{g} /$ disc ethnolic extract of garlic, turmeric, crown flower, and leaves of Indian lilac and mixed of crown flower and Indian lilac was mixed with $1 \mathrm{ml}$ bacterial solution and kept in ice box. Shrimps were injected with mixture of extract and bacterial solution at the ventral region of $2^{\text {nd }}$ abdominal segment at $45^{\circ}$ angle with the vertical axis of the shrimp body.

\subsubsection{Sampling Strategy}

Experimentally injected shrimps were sacrificed to collect organ of muscle. Then samples were collected at 24 hours after injection with a 3 hours interval. Two (2) shrimps at each time were sacrificed from each group of experiment. All the samples were marked properly and preserved in deep freeze $\left(-20^{\circ} \mathrm{C}\right)$ for further laboratory analysis.

\subsubsection{Enumeration of E. coli Load in Muscles with and without Extract}

At first enrichment of stock solution of each sample was done. Then obtained solution was serially diluted and cultured in Macconkey agar media at $37^{\circ} \mathrm{C}$ for $24 \mathrm{~h} \pm 3$ hours and E. coli enumeration was done.

\section{RESUltS AND DisCUSSION}

\subsection{Results}

The garlic, turmeric, crown flower, and leaves of Indian lilac and mixed of crown flower and Indian lilac were tested for the antibacterial activity against pathogenic E. coli bacterial strain at a concentration of $500 \mu \mathrm{g} / \mathrm{disc}$ and $1000 \mu \mathrm{g} / \mathrm{disc}$ through screening the zone of inhibition of the plant extracts and its comparison with standard antibiotic kanamycin $(30 \mu \mathrm{g} / \mathrm{disc})$. 


\subsubsection{Antibacterial Activity Test}

The ethanol extract of garlic, turmeric, crown flower, Indian lilac and mixed of crown flower and Indian lilac at the dose of $500 \mu \mathrm{g} / \mathrm{disc}$ and $1000 \mu \mathrm{g} / \mathrm{disc}$ showed antibacterial activity against all the experimental bacterial strains of $E$. coli isolated from shrimp farm. The inhibitory zone formed by standard antibiotic discs of kanamycin $(30 \mu \mathrm{g} / \mathrm{disc})$ against all test organisms, E. coli strains was more or less same constituting mean value of $20 \mathrm{~mm}$.

At the both concentration, the ethanol mixed extracts of crown flower and Indian lilac was most effective towards all $E$. coli strains compared to other experimental medicinal plant extracts. It showed higher inhibitory effects at the concentration of $1000 \mu \mathrm{g} / \mathrm{disc}$ than the low concentration $(500 \mu \mathrm{g} / \mathrm{disc})$. These mixed extracts was the highest inhibitory responded extracts against E. coli 119 $E A E$ creating $21 \mathrm{~mm}$ and $20 \mathrm{~mm}$ zone of inhibition at the doses of $1000 \mu \mathrm{g} / \mathrm{disc}$ and $500 \mu \mathrm{g} / \mathrm{disc}$ respectively followed by Indian lilac $(19 \mathrm{~mm})$ at the dose of $1000 \mu \mathrm{g} / \mathrm{disc}$ whereas in case of the remains three E. coli strains it acted as the medium inhibitory responded plants at the both concentration (Figure 1\&2).

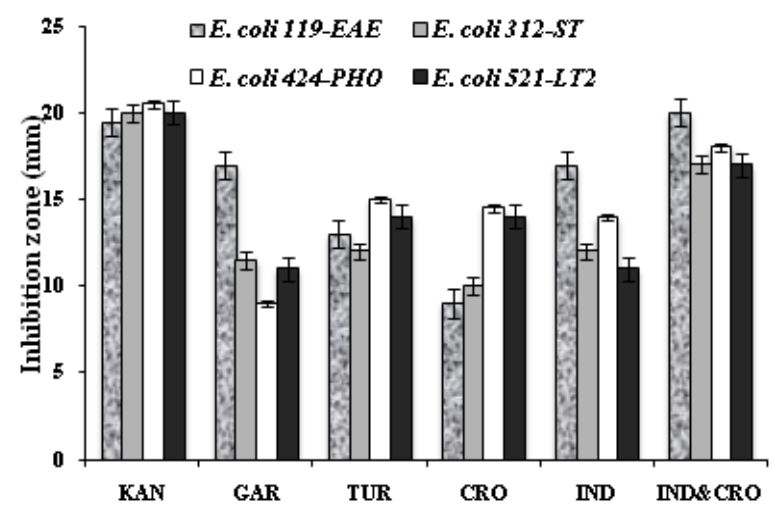

Fig1. Antimicrobial activity of medicinal plant extracts $(500 \mu \mathrm{g} /$ disc $)$. Values are expressed as mean \pm standard deviation of the three replicates. KAN indicates Kanamycin; Gar indicates garlic; TUR indicates turmeric; CRO indicates crown flower; IND indicates leaves of Indian lilac; IND\&CRO indicates mixed of crown flower and Indian lilac

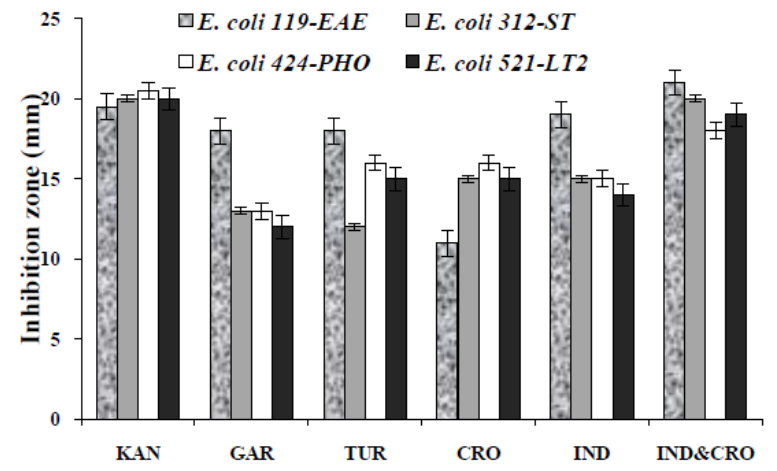

Fig2. Antimicrobial activity of medicinal plant extracts $(1000 \mu \mathrm{g} /$ disc $)$. Values are expressed as mean \pm standard deviation of the three replicates. KAN indicates Kanamycin; Gar indicates garlic; TUR indicates turmeric; $C R O$ indicates crown flower; IND indicates leaves of Indian lilac; IND\&CRO indicates mixed of crown flower and Indian lilac

In contrast to turmeric and crown flower, the rest two effectively inhibited the growth of E. coli 119$E A E$ among four bacterial strains and showed the similar effects screening a zone of $17 \mathrm{~mm}$ at $500 \mu \mathrm{g} /$ disc concentration. Extracts of garlic, turmeric and Indian lilac demonstrated medium to low inhibitory effects against E. coli strains 312-ST, 424-PHO, and 521-LT2 (Fig 1). At the higher concentration extract of crown flower showed the lowest activity index presenting inhibitory zone of $11 \mathrm{~mm}$ against $E$. coli $119-E A E$ whereas extract of garlic exhibited low activity against all experimental strains of $E$. coli except strain $119-E A E$ having $18 \mathrm{~mm}$ zone of inhibition. The maximum inhibitory effects of turmeric and Indian lilac as high inhibitory responded herbs against E. coli 119$E A E$ were observed to be $18 \mathrm{~mm}$ and $19 \mathrm{~mm}$ of zone of diameter respectively at the higher concentration. In case of $E$. coli 424-PHO, the zone of growth inhibition created by both turmeric and crown flower was equal $(16 \mathrm{~mm})$ at $1000 \mu \mathrm{g} / \mathrm{disc}$ (Fig 2). 


\subsubsection{In Vivo Challenge Test of Shrimp (P. Monodon)}

For in vivo challenge test, shrimp were injected with five different extracts of garlic, turmeric, crown flower and leaves of Indian lilac and mixed of crown flower and Indian lilac and challenged with $E$. coli through 24 hours observation. The antibacterial activity of these extracts was observed by comparing the average load of $E$. coli without and with extracts at $500 \mu \mathrm{g} / \mu \mathrm{l}$ and $1000 \mu \mathrm{g} / \mu \mathrm{l}$ concentration.

All the experimental extracts proved the antibacterial activity against pathogenic bacterial strains of $E$. coli inhibiting the growth of pathogenic bacterial strains of $E$. coli with more effectiveness at the concentration of $1000 \mu \mathrm{g} / \mathrm{ml}$ than that of $500 \mu \mathrm{g} / \mathrm{ml}$ of the extracts. Without applying of extract as control, the average load of $E$. coli isolated from shrimp was found to be $3.09 \times 10^{4} \mathrm{CFU} / \mathrm{g}$. Compared to the control, significant reduction of the population of $E$. coli in shrimp were observed through the experimental period ranging from $2.62 \times 10^{4}$ - to $2.11 \times 10^{4} \mathrm{CFU} / \mathrm{g}$.

When in vivo test was performed, turmeric showed the lowest activity in case of both concentration $\left(\mathrm{T}_{2} \& \mathrm{~T}_{7}\right.$ ) exhibiting the average load of E. coli of $2.53 \times 10^{4} \mathrm{CFU} / \mathrm{g}$ at the dose of $1000 \mu \mathrm{g} / \mu \mathrm{l}$ in muscle of shrimp whilst best result of antagonistic effect against $E$. coli was found using mixed extract of crown flower and Indian lilac $\left(\mathrm{T}_{10}\right)$. These reduced the population of E. coli from $3.09 \times 10^{4} \mathrm{CFU} / \mathrm{g}$ found in control to $2.11 \times 10^{4} \mathrm{CFU} / \mathrm{g}$ at the concentration of $1000 \mu \mathrm{g} / \mathrm{ml}$ within 24 hours of experimental period. However, after treatment with ethanolic extracts, there were considerable reductions of $E$. coli in shrimp at the highest concentration apart from use of turmeric (Table 1). In spite of observing very low effect of extract of turmeric compared to control to reduce the average load of E. coli in in vivo challenge test of this study the result was ultimately suited with another previous study [20].

Table1. In-vivo challenge test by comparing the average load of E. coli in shrimps without as control and with extractsin different treatments

\begin{tabular}{|l|c|}
\hline \multicolumn{1}{|c|}{ Treatments } & Average load of $\boldsymbol{E}$. coli isolated from shrimp (CFU/g) \\
\hline $\mathrm{T}_{\mathrm{c}}$ & $3.09 \times 10^{4}$ \\
\hline $\mathrm{T}_{1}$ & $2.39 \times 10^{4}$ \\
\hline $\mathrm{T}_{2}$ & $2.62 \times 10^{4}$ \\
\hline $\mathrm{T}_{3}$ & $2.41 \times 10^{4}$ \\
\hline $\mathrm{T}_{4}$ & $2.29 \times 10^{4}$ \\
\hline $\mathrm{T}_{5}$ & $2.19 \times 10^{4}$ \\
\hline $\mathrm{T}_{6}$ & $2.12 \times 10^{4}$ \\
\hline $\mathrm{T}_{7}$ & $2.53 \times 10^{4}$ \\
\hline $\mathrm{T}_{8}$ & $2.14 \times 10^{4}$ \\
\hline $\mathrm{T}_{9}$ & $2.12 \times 10^{4}$ \\
\hline $\mathrm{T}_{10}$ & $2.11 \times 10^{4}$ \\
\hline
\end{tabular}

\subsection{Discussion}

Plant extract may contain active component that have the ability to complex with extracellular and soluble proteins of the microbial cell and/or to complex with bacterial cell walls and disrupt microbial membranes [21]. Some extracts may have ability to intercalate with DNA, form ion channels in the microbial membrane, and have competitive inhibition of adhesion of microbial proteins to host polysaccharide receptors [22]. Deresse and Awole (2009) [23] also stated that garlic (A. sativum) has antimicrobial properties against Salmonella, Shigella and E. coli strain. In the present study, extracts of crown flower and Indian lilac among four medicinal plants used to observe the antibacterial activity exhibited the highest inhibitory responses against $E$. coli strains, especially $119-E A E$ at the highest concentration followed by Indian lilac. E. coli 119-EAE was most sensitive to all test extracts at the rate of $1000 \mu \mathrm{g} / \mathrm{disc}$ but crown flower whereas garlic demonstrated the lowest inhibitory responses to all test organisms apart from E. coli 119-EAE strains. Poonam et al. [24] found as same results using methanolic extracts against $E$. coli as the findings of the present study. Turmeric, crown flower and Indian lilac performed similar and medium inhibitory effects against E. coli 424-PHO and E. coli 521LT2. E. coli 312-ST was low sensitive to all extracts except mixed extracts of crown flower and Indian lilac at high concentration. In addition, it is important to mention that E. coli 312-ST was more resistant to all extracts except mixed extracts of crown flower and Indian lilac. It was shown that the concentration of $1000(\mu \mathrm{g} / \mathrm{disc})$ of extracts was more effective as compared to that of $500(\mu \mathrm{g} / \mathrm{disc})$ (Table 2). 
Table2. Inhibitory responses of medicinal plants against four strains of E. coli

\begin{tabular}{|c|c|c|c|c|c|c|c|c|}
\hline \multirow[t]{3}{*}{ Extracts } & \multicolumn{8}{|c|}{$\begin{array}{l}\text { Inhibitory response of herbal extracts on growth of bacterial strains in two different } \\
\text { concentration }\end{array}$} \\
\hline & \multicolumn{2}{|c|}{ E. coli 119-EAE } & \multicolumn{2}{|c|}{ E. coli 312-ST } & \multicolumn{2}{|c|}{ E. coli 424-PHO } & \multicolumn{2}{|c|}{ E. coli 521-LT2 } \\
\hline & $500 *$ & $1000 *$ & $500 *$ & $1000 *$ & $500 *$ & $1000 *$ & $500 *$ & $1000 *$ \\
\hline GAR & ++ & +++ & + & + & + & + & + & + \\
\hline TUR & + & +++ & + & + & ++ & ++ & ++ & ++ \\
\hline $\mathrm{CRO}$ & + & + & + & ++ & ++ & ++ & ++ & ++ \\
\hline IND & ++ & +++ & + & ++ & ++ & ++ & + & ++ \\
\hline CRO\&IND & +++ & +++ & ++ & +++ & +++ & +++ & ++ & +++ \\
\hline
\end{tabular}

$+++=$ High response, $++=$ Medium response, $+=$ Low response and $* \mu \mathrm{g} /$ disc

The efficacy test of medicinal plants viz., garlic, turmeric, crown flower and leaves of Indian lilac and mixed of crown flower and Indian lilac on pathogenic $E$. coli bacterial strains is essential to evaluate the antimicrobial effect of the extract. Herbal products like garlic (A. sativum), Indian lilac (A. indica), and turmeric $(C$. longa $)$ are known to have antiviral and antibacterial activities [25, 26 and 27]. The antibacterial activity of Indian lilac against Aeromonas hydrophila, Pseudomonas fluorescens, Escherichia coli and Myxobacteria was tested as well [13]. Ethanol and methanol extracts of Indian lilac leaves created zone of inhibition of 15 and $14 \mathrm{~mm}$ respectively against $E$. coli [28] and the significant activity of the methanolic extract of the Indian lilac against E. coli showing an inhibitory zone diameter $(2.0 \mathrm{~cm}, 2.2 \mathrm{~cm}, 2.4 \mathrm{~cm}$ and $2.1 \mathrm{~cm})$ [24] supports the findings of the present study. A comparable experiment was conducted between commonly used antibiotics and the extracts of $A$. indica by disc diffusion method which had the similar effects on the bacteria [29]. It is suggested that Gram-positive organisms are more sensitive to A. indica than Gram-negative organisms because of its more complex nature of the cell wall [30]. The results of antimicrobial activity of $C$. gigantea against four microorganisms such as E. coli $(15 \mathrm{~mm})$, Vibrio mimicus $(15 \mathrm{~mm})$, Vibrio parahemolytics $(15 \mathrm{~mm})$ and Staphylococcus aureus (9mm) [31] correlates with this study. The study was also carried out to investigate whether the administration of ethanolic extract of garlic, turmeric, crown flower, Indian lilac and mixed extract of crown flower and Indian lilac through injection is capable of protecting $P$. monodon from pathogenic bacteria $E$. coli and it was successfully proved that there was strong antagonistic activity of ethanolic mixed extract of crown flower and Indian lilac against the strain of $E$. coli. In case of garlic against $E$. coli, same observation was found at concentration of $2.26 \mathrm{mg} / \mathrm{ml}$ and reported that garlic extract has inhibitory effect on shrimp farm bacterial flora and may be applicable in controlling bacterial diseases of shrimp [32]. 2\% olive leaves extracts (OLE) can control the microbial load (aerobic and coliforms bacteria) in PUD shrimp stored at $4{ }^{\circ} \mathrm{C}$ and it was demonstrated that OLE might be beneficial to the fish processing industry as a natural preservative [33]. In other studies, Labeo rohita orally administered with extracts of A. sativum [34] as well as Lates calcarifer with extracts of $A$. indica [35] have shown in vivo efficacy when they were challenged against $A$. hydrophila and Vibrio harveyi respectively compared to control groups. The difference in the effect of these plant extracts within the organisms is that there are different antibacterial compounds in the plant extracts and that the compound that acted on one may not be the same as the one that acted on the others since antibacterial agents have different modes of action [36]. It is suggested that further work has to be done to examine the specific component(s) present in medicinal plants responsible for the effect on different bacterial strains.

\section{Conclusion}

The extracts of garlic, turmeric, crown flower and Indian lilac possessed good quality antibacterial activity confirming the immense potential of bioactive ingredients and may be used in primary health care as alternative medicine instead of antibiotics to avoid side effects. Mixed extracts of crown flower and Indian lilac exhibited remarkable biological control against $E$. coli strains. They can play a significant role in shrimp farming as an effective antibacterial agent to cure the bacterial disease caused by $E$. coli having cost-effective and eco-friendly. They can serve as therapeutic agents as well as important raw materials for the manufacture of traditional and modern medicine for their some advantages with fewer side effects and relatively less expenses.

\section{ACKNOWLEDGEMENT}

The financial support provided by the Khulna University Research Cell for this study is greatly acknowledged. We also appreciate Md. Nazmul Hasan Zilani, Pharmacy Discipline, Khulna University for his assistance in the Laboratory. 


\section{REFERENCES}

[1] Inglis, V., Use of Chemicals in Aquaculture in Asia: Antibacterial chemotherapy in aquaculture: review of practice, associated risks and need for action, eds. Arthur, J. R., C. R. Lavilla-Pitogo and R. P. Subasinghe, Tigbauan, Iloilo, Philippines, 7-22 (1996).

[2] Roberts, R. J., Aquatic animal health towards, In: Diseases in Asian Aquaculture II, eds. M. Shariff, T. R. Arthur, R. P. Subasinghe 2000, Fish Health Section, Asian Fisheries Society, Manila, 3-7(1995).

[3] Smith, P., Heny, M. P. and Samuelsen, S. B., Bacterial resistance to antimicrobial agent used in fish farming: a critical evaluation of method and meaning, Annual Review of Fish Diseases, 4, 273-313 (1994).

[4] Cunha, B. A., Antibiotic side effects, Med. Clinics North Am., 85,149-185 (2001).

[5] Vermani, K. and Garg, S., Herbal Medicines for Sexually Transmitted Diseases and AIDS, J. Ethnopharmacol. 80, 49-66 (2002).

[6] Muniruzzaman, M. and Chowdhury, M. B. R., Sensitivity of fish pathogenic bacteria to various medicinal herbs, Bangladesh J. Vet. Med., 2 (1), 75-82 (2004).

[7] Tepe, B., Daferera, D., Sokmen, M., Polissiou, M., and Sokmen, A., In vitro antimicrobial and antioxidant activities of the essential oils and various extracts of thymus, J. Agri and Food Chem., 52,1132-1137 (2004).

[8] Bajpai , M., Pande, A., Tewari, S. K. and Prakash, D., Phenolic contents and antioxidant activity of some food and medicinal plants, Int J Food Sci Nutr., 56(4), 287-291(2005).

[9] Wojdylo, A., Oszmianski, J. and Czemerys, R., Antioxidant activity and phenolic compounds in 32 selected herbs, Food chemistry, 105, 940-949 (2007).

[10] Direkbusarakom, S. and Aekpanithanpong, U., The efficacy of the crude extract from the leaf of guava (Psidium guajava L.) on Vibrio spp. isolated from diseases tiger prawn (Penaeus monodon), Proceedings of the Seminar on Fisheries, Department of Fisheries, Pp 259-262 (1992).

[11] Rao, C.N.R., Giant Magnetoresistance Phenomenon in Manganates, 2(12), 1499-1504 (1996).

[12] Kraus, W., Azadirachtin and other triterpenoids, Biologically Active Ingredients, ed. Schmutterer, H., The Indian lilac Trees, New York, USA: VCH Publishers Inc. 1995, Ch 2, Pp 35-73.

[13] Das, B. K., Mukherjee, S. C., Sahu, B. B. and Murjani, G., Indian lilac (Azadirachta indica) extract as an antibacterial agent against fish pathogenic bacteria, Indian J. Exp. Biol., 37(11), 1097-1100 (1999).

[14] Dastur, J. F., Medicinal plants of India and Pakistan, Published by D.B. Taraporevala Sons \& Co. Private Ltd., 210, Dr. Dadabhai Naorojii Road, Bombay 400 001, 201(1977).

[15] Chowdhury, A. K., Ahsan, M., Islam, S.N. and Ahmed, Z.U., Efficacy of aqueous extract of garlic and allicin in experimental shigellosis in rabbits, Indian J. Med. Res., 93, 6-33 (1991).

[16] Rahman, M. M., Efficacy of medicinal plants against bacterial fish pathogens, M.S. Thesis, Department of Aquaculture, Bangladesh Agricultural University, Mymensingh, Bangladesh. Pp 73 (2005).

[17] Chowdhury, M.B.R and Muniruzzaman, M., Causative agents of ulcer type of disease in farmed and wild fishes in Mymensing area. BAU Research Progress, 12, 136-138 (2002).

[18] Bauer, A.W., Kirby, W.M.M., Sherris, J.C., and Turck, M., Antibiotic susceptibility testing by a standardized single disk method. Am. J. Clin. Pathol. 45, 493-496 (1966).

[19] Ríos, J. L., Recio, M. C. and Villar, A., Screening methods for natural products with antimicrobial activity: a review of the literature, J. Ethnopharmacol., 23, 127-149 (1988).

[20] Rahman, T., Akanda, M.M.R, Rahman, M.M., and Chowdhury, M.B.R., Evaluation of the efficacies of selected antibiotics and medicinal plants on common bacterial fish pathogens. J. of the Bangladesh Agri. Uni., 7:163-168 (2009).

[21] Ali, A. A., Studies on some medicinal plants as a source of antifungal substances in North Africa, M.Sc. Thesis, Inst. of African Res. and Studies, Cairo Univ. (1999).

[22] Cowan, M. M., Plant Products as antimicrobial agents, Clin. Microbiol. Rev., 12(4), 564-582 (1999).

[23] Deresse, D. and Awole, M., Assessment of the antibacterial effect of crude preparation of garlic 
(A. sativum) on diarrhoea causing bacteria: an in vitro study, Asian J. of Medical Sciences, 1(1), 12-14 (2009).

[24] Poonam, P., Himani, B. and Shivangi, M., Azadirachta indica (Indian lilac): antibacterial effects against Escherichia coli and Salmonella, Guru Drone J. of Pharm. and Res., 1(1), 18-21 (2013).

[25] Ammon, H. P. T., Safayhi, H., Mack, T. and Sabieraj, J., Mechanism of anti-inflammatory action of curcumin and boswellic acids, J. Ethnopharmacol., 38, 113-119 (1993).

[26] Kumar, M. and Berwal, J. S., Sensitivity of food pathogens to garlic (Allium sativum), J. Appl. Microbiol., 84, 213-215 (1998).

[27] Sasmal, D.and Abraham, T. J., Effect of garlic (Allium sativum) extract on the growth and disease resistance of Carassius auratus (Linnaeus, 1758), Indian J. Fish., 52(2), 207-214 (2005).

[28] Dhayanithi, N. B. Kumar, T. T. A. and Kathiresan, K., Effect of Indian lilac extract against the bacteria isolated from marine fish, J. of Env. Biology, 409-412 (2010).

[29] Mamman, P. H., Mshelia, W. P., Susbatrus, S. C. and Sambo, K. W., , Antibacterial effects of crude extract of Azadirachta indica against Escherichia coli, Salmonella spp and Staphylococcus aureus, Int. J. of Medicine and Medical Sci., 5(1), 14-18 (2013).

[30] Yoa, J. and Moellering, R., Antibacterial agents. Manual of Clinical Microbiology, ASM, Washington, DC. 1281-1290 (1995).

[31] Rahman, M. S., Moly, N. N. and Hossen, M. J., Antimicrobial, cytotoxic and antioxidant activity of the exudate of Calotropis gigantean, Int. J. of Pharmaceutical Sci and Res, 4(2), 745753(2013).

[32] Sasmal, D. and Abraham, T. J., In vitro inhibitory activity of garlic (Allium sativum), Indian lilac (Azadirachta indica) and turmeric (Curcuma longa) against shrimp farm bacterial flora. J. Inland Fish. Soc. India 39(2), $59-61$ (2007)

[33] Ali, M. A., Nancy, S. R., Aboubaker, M. G., Said, K. A., Antibacterial effect of olive (Olea europaea) leaves extract in raw peeled undeveined shrimp (Penaeus semisulcatus), Int. J. of Veterinary Science and Medicine, 2 (1), 53-56 (2014).

[34] Sahu, B.K.D., Das, B.K., Mishra, B.K., Pradhan, J., Sarangi, N., , Effect of Allium sativum on the immunity and survival of Labeo rohita infected with Aeromonas hydrophila, J. Appl. Ichthyol. 23, 80-86 (2007).

[35] Talpur, A. D., and Ikhwanuddin, M., , Azadirachta indica (neem) leaf dietary effects on the immunity response and disease resistance of Asian seabass, Lates calcarifer challenged with Vibrio harveyi, Fish Shellfish Immunol. 34, 254-264 (2013).

[36] Aliu, Y.O., Pharmacodynamics: Veterinary Pharmacology (1st Ed.), Tamaza 29 publisher, Nigeria, 8-16 (2007).

\section{AUTHORS' BIOGRAPHY}

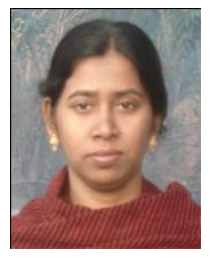

Momotaz Khanom, has been working as a faculty in Fisheries and Marine Resource Technology Discipline at Khulna University since 2003. She has got her B. Sc in 1996, M. Sc in 2003 in Fisheries and Marine Resource Technology and presently is carrying on $\mathrm{PhD}$ in Fish population Biology in the same Discipline at Khulna University. Furthermore, now she is conducting research on specific biological and ecological characteristics for several allophonic fish species in freshwater of Croatia at the

Department of Fisheries, Beekeeping, Game Management and Special Zoology, Faculty of Agriculture, University of Zagreb, Croatia.

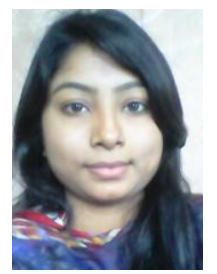

Sharmin Sultana Khushi, is going on Master of Science in Fish Genetics and Biotechnology and got her Bachelor of Science in Fisheries (Honours) in 2013 from Khulna University, Bangladesh.

Dr. Md. Golam Sarower, has been working as Professor in Fisheries and Marine Resource Technology Discipline at Khulna University since 1997. He has got his B. Sc (1996) in Fisheries and Marine Resource Technology Discipline, M. Sc (2001) and PhD (2004) in University of Tokyo. 